\title{
Three Wall Orbital Decompression for Compressive Optic Neuropathy in Thyroid Ophthalmopathy
}

\author{
Ji Ah Song', Joo Yeon Kim¹, Soo Jung Lee ${ }^{2}$, and Jae Hwan Kwon ${ }^{1}$ \\ ${ }^{1}$ Department of Otolaryngology-Head and Neck Surgery, Kosin University College of Medicine, Busan; and \\ ${ }^{2}$ Department of Ophthalomology, Inje University Haeundae Paik Hospital, Busan, Korea
}

\section{삼면 안와감압술로 치료한 갑상샘 눈병증에서 발생한 압박시신경병증}

송지아 ${ }^{1} \cdot$ 김주연 $^{1} \cdot$ 이수정 ${ }^{2} \cdot$ 권재환 $^{1}$

고신대학교 의과대학 이비인후과학교실, ${ }^{1}$ 인제대학교 의과대학 해운대백병원 안과학교실 ${ }^{2}$

\author{
Received May 25, 2017 \\ Revised July 7, 2017 \\ Accepted July 17, 2017 \\ Address for correspondence \\ Jae Hwan Kwon, MD, PhD \\ Department of Otolaryngology- \\ Head and Neck Surgery, \\ Kosin University \\ College of Medicine, \\ 262 Gamcheon-ro, Seo-gu, \\ Busan 49267, Korea \\ Tel $+82-51-990-6247$ \\ Fax $+82-51-245-8539$ \\ E-mail entkwon@hanmail.net
}

Thyroid ophthalmopathy is an autoimmune disease that affect the orbital and periorbital soft tissue, characterized by bulging eye (exophthalmos) and compressed orbital structures, such as the optic nerves. The indications for surgical treatment for thyroid ophthalmopathy include decreased visual acuity caused by optic neuropathy, conjunctivitis and progressive facial deformity caused by exophthalmos. Orbital wall decompression by nasal endoscopy resulte in good cosmetic effects and visual recovery. Balanced orbital decompression is considered to be a safe and effective surgery that can help avoid postoperative diplopia. We introduce three successful cases of orbital wall decompression for the treatment of thyroid ophthalmopathy. Korean J Otorhinolaryngol-Head Neck Surg 2019;62(2):125-30

Key Words Graves opthalmopathy · Orbital decompression · Thyroid eye disease.

\section{서 론}

갑상샘 눈병증은 자가면역기전에 의한 염증 반응이 일어 나 안와의 구조물을 침범하는 질환으로 외안근이나 안와 지 방에 림프구성 침윤이 발생하고 부피가 점점 늘어나 안구돌 출이 발생하며, 시신경 등 안와 구조물을 압박하게 된다. 갑 상샘 눈병증에서 안와감압술의 적응증은 압박시신경병증으 로 인한 시력 감소, 안구돌출에 의한 노출 각막염, 심한 안구 돌출로 인해 얼굴의 모습이 변형된 경우 등이며, 수술의 목 적은 안와 지방을 제거하거나 안와 주위벽을 제거하여 시신 경에 대한 압력을 완화하며 시력을 회복시키고 안구돌출을 호전시키는 데 있다. ${ }^{1,2)}$ 안와감압술의 수술 접근법으로 결막 경유법(transconjunctival), 상악동 경유법(transantral), 내시경
적 비내접근법(endoscopic transnasal), 누구접근법(transcaruncular) 등이 있고, 현재까지는 결막 경유법과 상악동 경유법 이 가장 많이 시행되고 있다.,3-5) 내시경적 비내접근법은 1990 년 Kennedy 등 ${ }^{4,6,7)}$ 이 처음 시도했으며, 외부에 흥터를 남기지 않고 하사근, 내안각 인대 및 코눈물관, 안와아래신경 등의 주변 구조물에 손상을 주지 않으면서 충분한 안구돌출 교정 효과를 얻을 수 있고 안와첨의 가장 깊숙한 부분까지 접근이 용이하여 압박시신경병증을 효과적으로 회복시킬 수 있는 것 으로 알려져 있다. ${ }^{6,7)}$ 저자들은 갑상샘 눈병증에 의한 압박시 신경병증으로 시력 감소 및 안구돌출이 진행되던 환자에서 내시경을 이용한 비내접근법과 결막 경유법으로 삼면 안와 감압술을 시행한 3예를 경험하였기에 이를 보고하고자 한다.

This is an Open Access article distributed under the terms of the Creative Commons Attribution Non-Commercial License (http://creativecommons.org/licenses/by-nc/4.0) which permits unrestricted non-commercial use, distribution, and reproduction in any medium, provided the original work is properly cited. 


\section{증 례}

\section{증 례 1}

52세 여자 환자가 내원 1개월 전부터 서서히 시작된 복시, 양 안의 안구돌출을 주소로 내원하였다. 기저질환으로는 갑상선 기능항진증, 고혈압, 당뇨가 있었으며, 초진 시 교정시력은 우 안 1.0, 좌안 0.9 , 안압은 우안 $17 \mathrm{~mm} \mathrm{Hg}$, 좌안 $16 \mathrm{~mm} \mathrm{Hg}$ 였 으며, 안저검사에서 특이 소견은 보이지 않았다. Hertel 안구 돌출계 검사에서 우안 $23.5 \mathrm{~mm}$, 좌안 $23 \mathrm{~mm}$ (bar: 104)로 양 안의 안구돌출을 보였으며(Fig. 1A), 안구운동검사에서 모든 안위에서 양안의 안구운동 제한이 관찰되었다. 안면부 컴퓨터 단층촬영에서 네 개 외직근의 비후 소견 및 양안의 심한 안구 돌출이 보였으며, 안와 자기공명영상촬영에서 양안의 시신경 부종과 시신경 주위 조영 증강이 관찰되었다(Fig. 2A and B). 양안의 갑상샘 눈병증으로 진단하고 스테로이드 $50 \mathrm{mg}$ 경구 투여를 시작하였지만 상기 증상이 더 심해지고 5일간 스테로 이드(Prednisolon) $500 \mathrm{mg}$ 정맥 투여 후 일주일 간격으로 4 번 더 주사하였지만 호전되지 않아 수술적 치료를 결정하였 다. 수술 전 교정시력이 우안 0.5 , 좌안 0.5 , 안압 우안 $21 \mathrm{~mm}$ $\mathrm{Hg}$, 좌안 $18 \mathrm{~mm} \mathrm{Hg}$, 안구돌출계는 우안 $25.5 \mathrm{~mm}$, 좌안 26.5 $\mathrm{mm}$ (bar: 104)로 안구 증상이 더 악화되었다. 내시경을 이용 한 비내접근법으로 양안의 안와 내벽, 내하벽감압술을, 외안 각 접근법으로 외벽감압술을 시행하였다. 수술은 전신마취하 에 진행되었으며, 내시경을 이용하여 비내접근법으로 사골동 절제술을 시행한 후 상악동 자연공을 넓혀 안와 내벽과 하벽 의 뼈를 노출시켰다. 뒤쪽으로는 시신경관(optic canal)부터,
앞쪽으로는 전두함요(frontal recess)까지, 바깥쪽으로는 하안 와신경(infraorbital nerve)의 내측까지 안와 내 하벽을 제거한 후, 노출된 골막에 12 번 나이프를 이용하여 수평으로 3 개의 절개선을 넣어 안와 지방이 비강 내로 돌출되도록 하여 안와 내 부피를 감소시켰다. 안와 외벽감압술을 위해 외안각을 수 평으로 절개한 후 하안검 결막을 절개하고 골막을 거상하여 드릴로 안와 외벽을 제거하였고, 골막에 나이프를 이용하여 수평으로 절개를 넣어 안와 지방이 돌출되도록 하였다. 수술 후 4일째부터 양안 모두 교정시력 1.0으로 개선되었고, 안구 돌출계는 우안 $21.5 \mathrm{~mm}$, 좌안 $22.5 \mathrm{~mm}$ (bar: 104)로 양안에서 $4 \mathrm{~mm}$ 의 안구돌출 교정 효과가 있었으며, 복시 및 안구운동 제한은 호전되었다(Figs. 1B, 2C and D). 현재 수술 후 24개월 동안 안구돌출 등의 재발 없이 경과관찰 중이다.

\section{증 례 2}

57 세 여자 환자가 지속적으로 심해지는 좌안의 안구돌출을 주소로 전원되었다. 환자는 갑상선 기능항진증으로 타 병원 내과에서 약물 복용 중이었으나 최근 2 개월간 좌안의 안구 돌출로 안과에서 스테로이드 및 면역 억제제를 투여받았음 에도 지속적으로 안구돌출이 심해져 수술적 치료를 위해 본 원으로 전원되었다. 안구돌출계상 양안 차이가 2개월 전 2 $\mathrm{mm}, 1$ 개월 전 $4 \mathrm{~mm}$, 본원 이비인후과 외래 방문 시 $6 \mathrm{~mm}$ 로 점점 심해지는 양상이었으며 시력은 변화 없었으나 간헐적인 복시를 호소하였다(Fig. 3A). 안면부 컴퓨터단층촬영에서 좌 안의 안구 내직근 및 하직근이 비후되어 있었으며, 우안의 오 래된 안와 내벽 골절 소견이 보였으나 과거력상 안와 주위
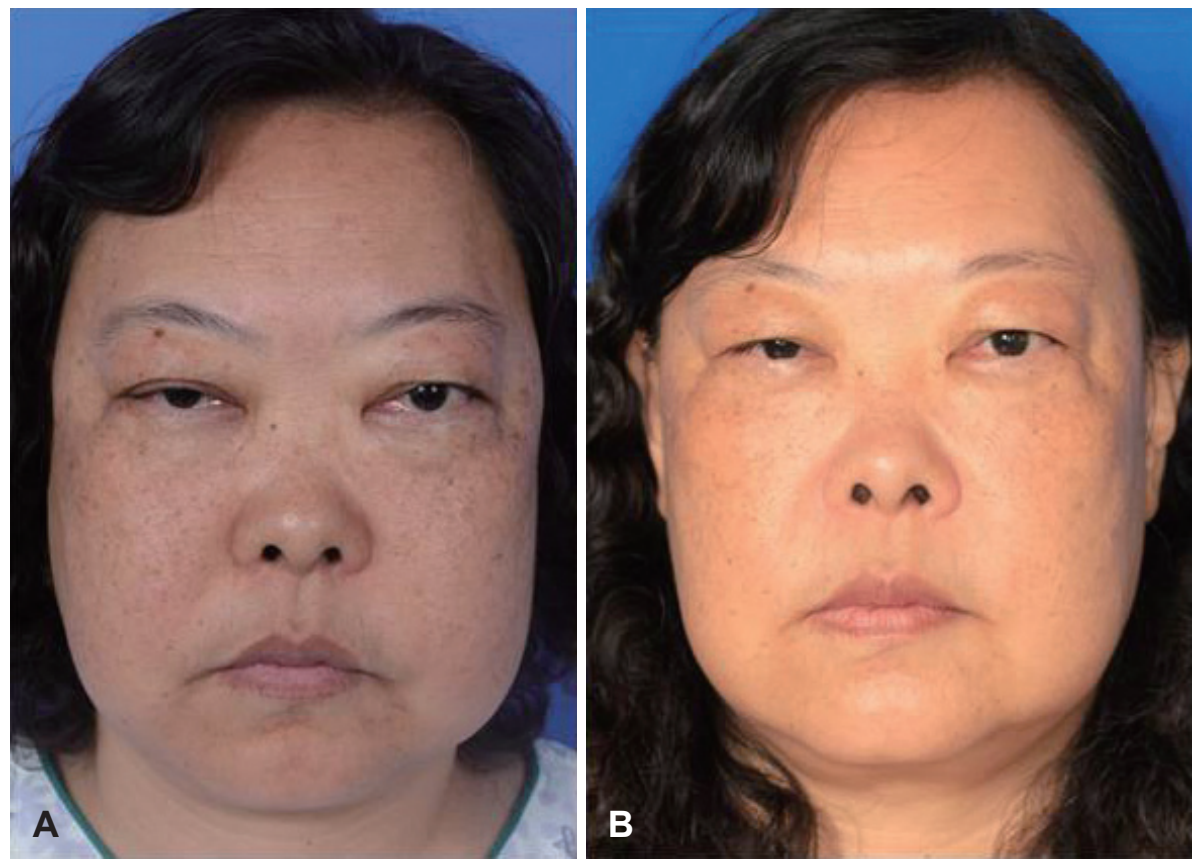

Fig. 1. Preoperative photo (case 1 ) shows mild conjunctival chemosis and severe exophthalmos $(25.5 \mathrm{~mm} /$ $26.6 \mathrm{~mm}$ ) in both eyes (A). Postoperatively, exophthalmos was improved by $4 \mathrm{~mm}$ in both eyes from $25.5 \mathrm{~mm}$ to $21.5 \mathrm{~mm}$ in the right eye and from $26.6 \mathrm{~mm}$ to $22.5 \mathrm{~mm}$ in the left eye, respectively (B). 
수상 및 안구 수술의 병력은 없었다(Fig. 4A and B). 좌안의 안구돌출이 우측 안와의 내벽골절로 인한 가능성이 있지만, 최근 2 개월간 $4 \mathrm{~mm}$ 이상 심해져서 갑상선 안구병증으로 인 한 안구돌출로 판단하고 수술적 치료를 계획하였다. 수술은
첫 번째 환자와 같이 내시경적 비내접근법으로 좌안의 안구 내벽 및 하내벽감압술을, 외부접근법으로 안와 외벽감압술 을 시행하였다. 수술 직후 복시 등 수술과 관련된 합병증은 없으며, 술 후 2 개월째 술전에 비해 안구돌출계 검사상 양안
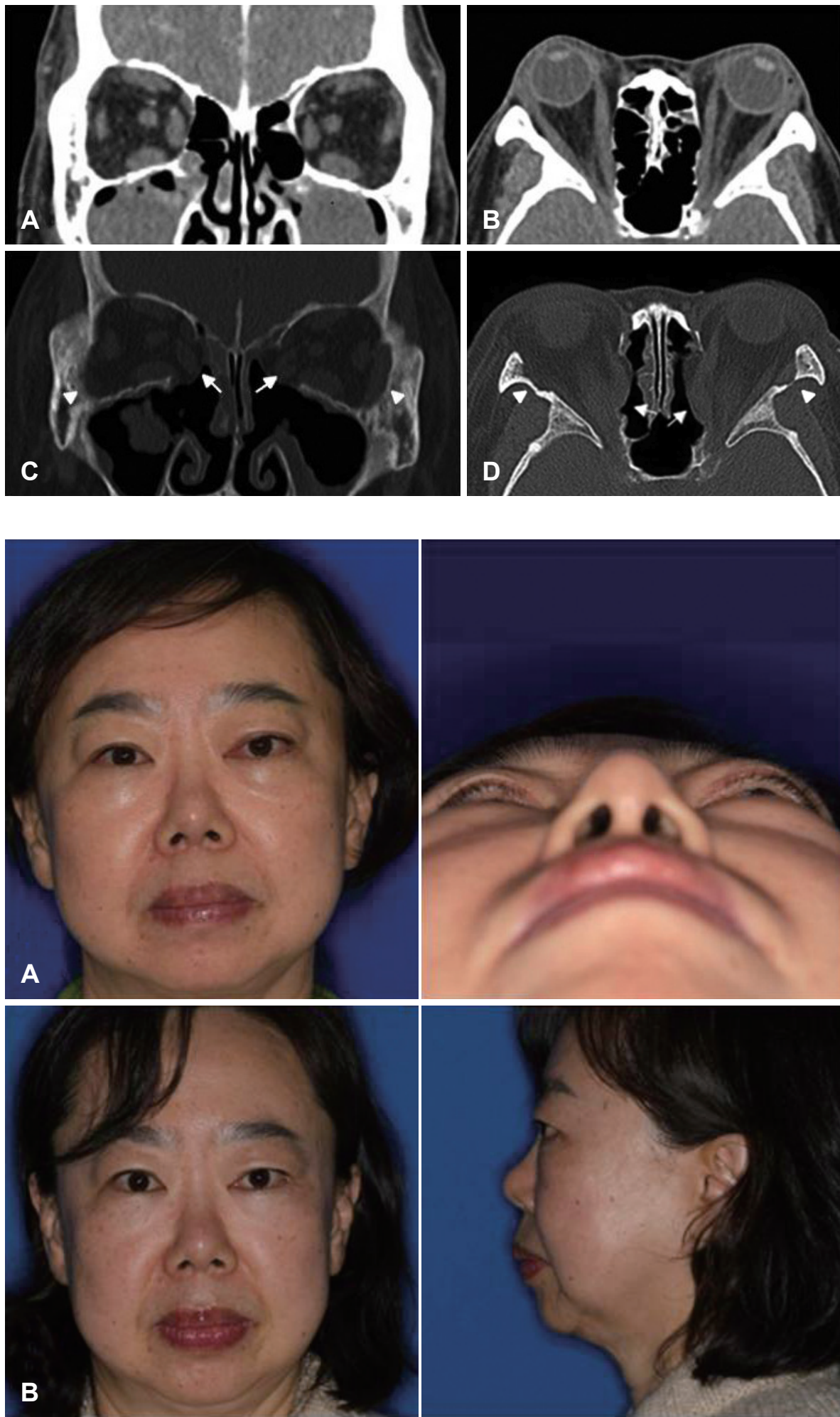

D
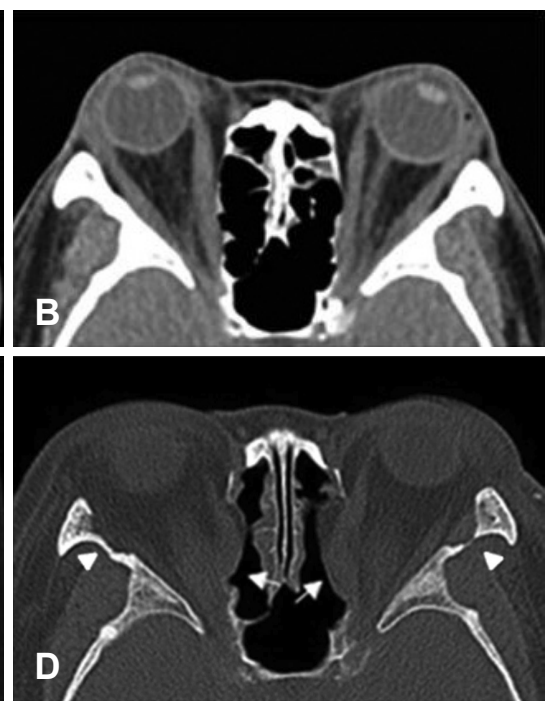

Fig. 2. Preoperative coronal CT scan (case 1) shows severe enlargement of all rectus muscles (A). Axial view shows the distinct exophthalmos in both eyes (B). Postoperative coronal CT scan shows the effect of bilateral medial, inferomedial wall (arrows) and lateral wall removal (arrowheads). Medial rectus muscle and orbital fat tissue were extruded to nasal cavity, which decrease orbital volume and pressure (C). Axial view shows loss of medial (arrows) and lateral wall (arrowheads) of both orbit and improvement of exophthalmos in both eyes compared to preoperative one (D).
Fig. 3. Preoperative photos (case 2) show severe exophthalmos of left orbit (A). Postoperatively, left exophthalmos was improved by $4 \mathrm{~mm}(B)$. 
차이 $2 \mathrm{~mm}$ 로 호전되었으며 술 후 18 개월째 양안 차이 없이 경과관찰 중이다(Figs. $3 \mathrm{~B}, 4 \mathrm{C}$ and $\mathrm{D}$ ).

증 례 3

53세 남자 환자로 양안의 복시와 안구돌출을 주소로 내원
하였다. 우안이 좌안에 비해 돌출이 심하며 우안이 잘 감기지 않아 간헐적인 우안 통증을 호소하였다. 환자는 갑상선 기능 항진증으로 타 병원에서 약물 복용 중이었으며 상기 증상 발 생하여 2개월간 스테로이드를 투여하였지만 증상 호전 없이 악 화되는 소견으로 수술적 치료 위해 본원으로 전원되었다. 초
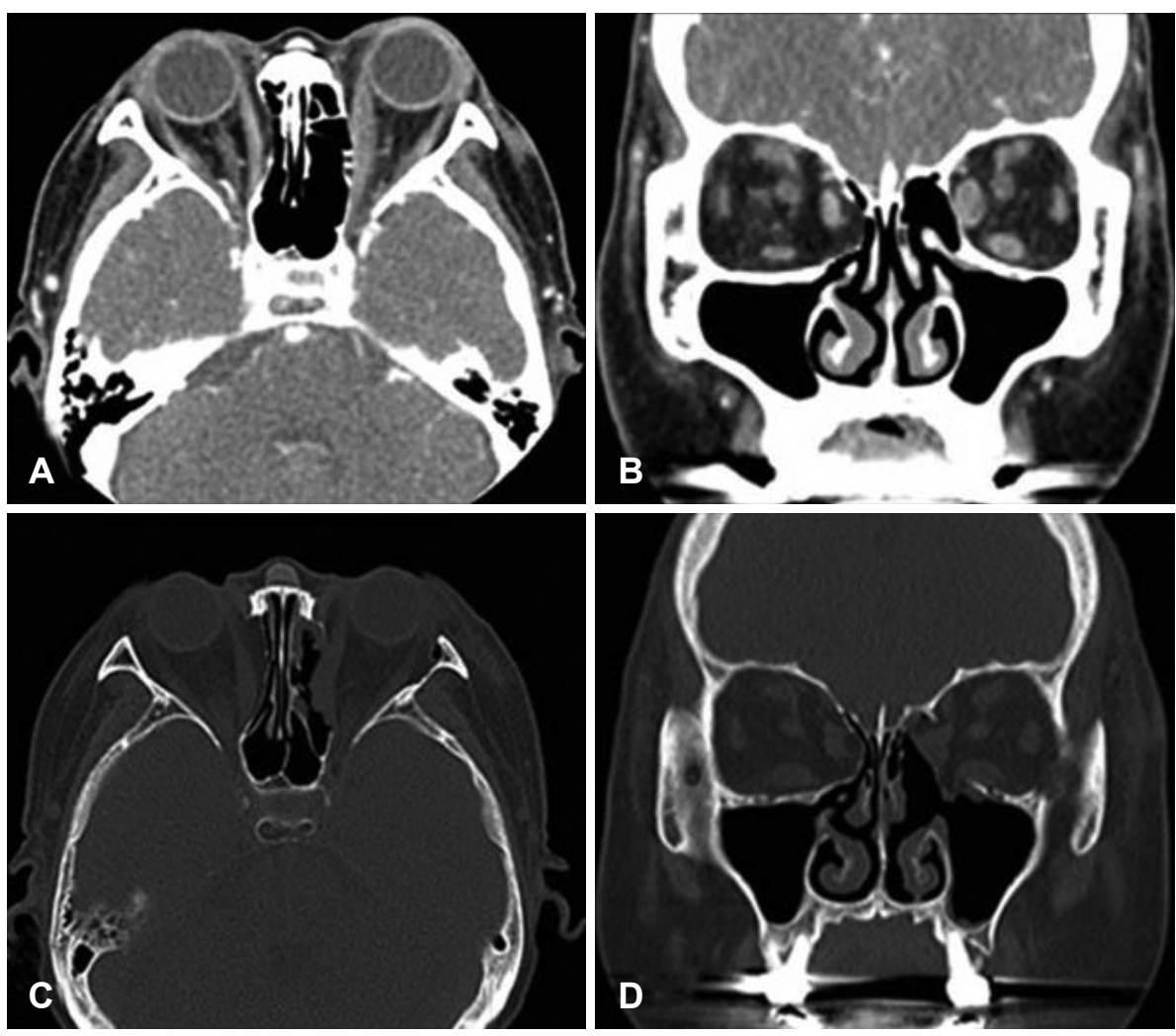

Fig. 4. Preoperative Axial CT scan (case 2) shows the distinct exophthalmos in left eye (A). Coronal view shows severe enlargement of left rectus muscles (B). Postoperative axial view shows loss of medial and lateral wall of left orbit and improvement of exophthalmos in left eye (C). Coronal CT scan shows the effect of medial, inferomedial wall and lateral wall removal of left orbit (D).
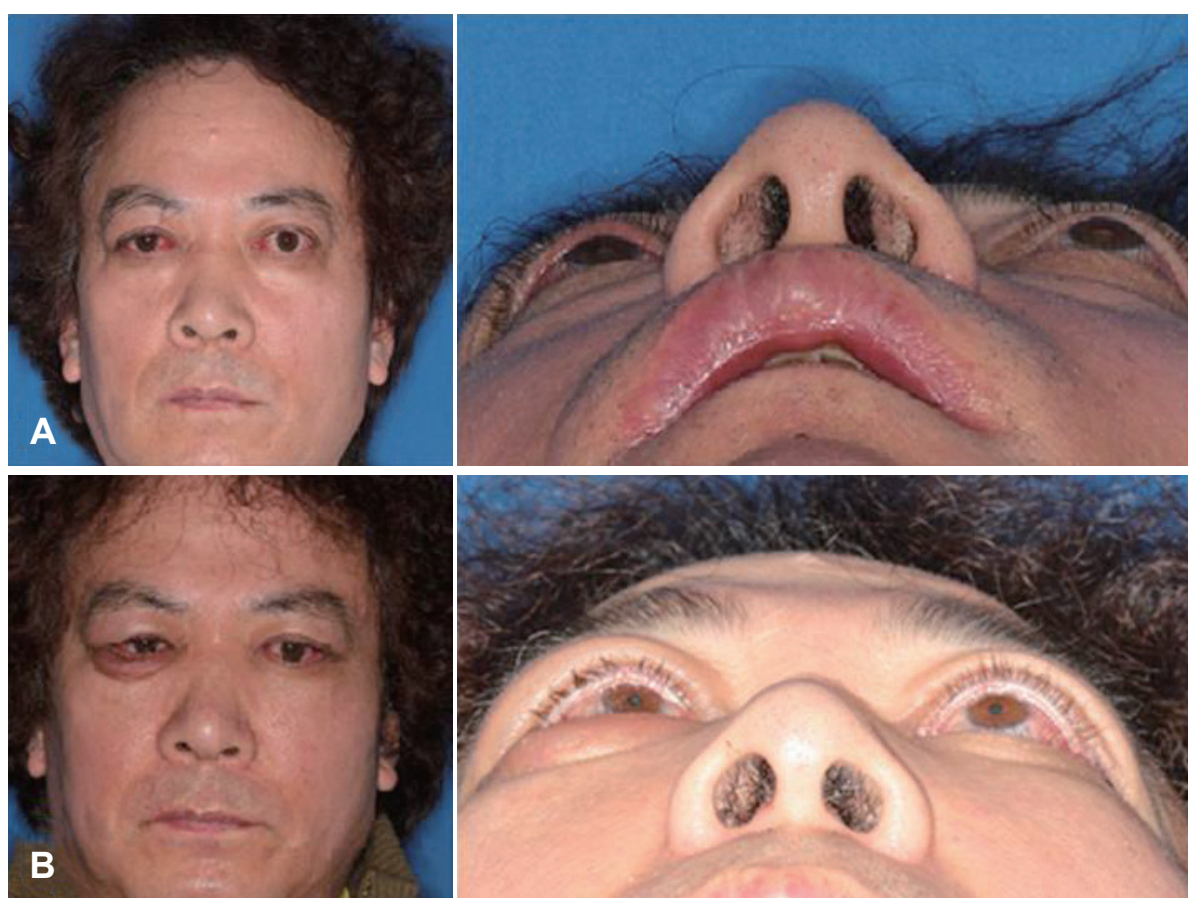

Fig. 5. Preoperative photo (case 3) shows conjunctival chemosis and severe exophthalmos $(25 \mathrm{~mm} / 23$ $\mathrm{mm}$ ) in both eyes (A). Postoperatively, exophthalmos was improved from $25 \mathrm{~mm}$ to $19 \mathrm{~mm}$ in the right eye and from $23 \mathrm{~mm}$ to $18 \mathrm{~mm}$ in the left eye (B). 

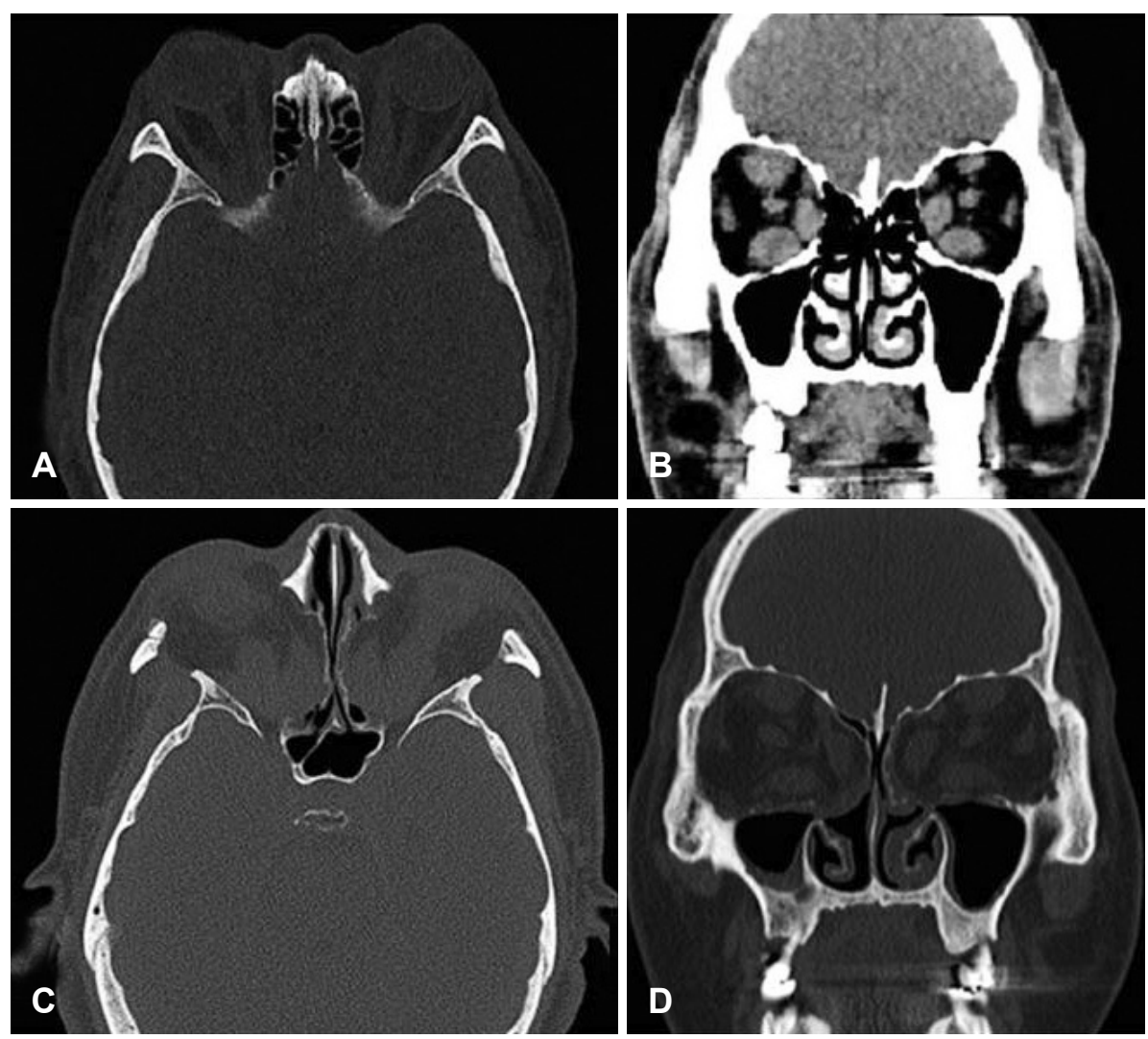

Fig. 6. Preoperative Axial CT scan (case 3) shows the distinct exophthalmos in both eyes (A). Coronal view shows severe enlargement of all rectus muscles $(B)$. Postoperative axial view shows loss of medial and lateral wall of orbit and improvement of exophthalmos in both eyes (C). Coronal view of facial bone CT scan shows the effect of medial, inferomedial wall and lateral wall removal (D).

진 시 교정시력은 우안 0.2, 좌안 1.0 , 안압은 우안 $20 \mathrm{~mm} \mathrm{Hg}$, 좌안 $20 \mathrm{~mm} \mathrm{Hg}$ 였으며, Hertel 안구돌출계 검사에서 우안 $25 \mathrm{~mm}$, 좌안 $23 \mathrm{~mm}$ 로 양안의 안구돌출을 보였으며, 안구 운동검사에서 모든 안위에서 양안의 안구운동 제한이 관찰 되었다. 또한 안구돌출로 인한 장기간의 안구 노출로 양안의 각막염 소견이 관찰되었다(Fig. 5A). 안면부 컴퓨터단층촬영 에서 네 개 외직근의 비후 소견 및 양안의 심한 안구돌출이 보였다(Fig. 6A and B). 양안의 갑상샘 눈병증으로 진단하고 수술적 치료를 계획하였다. 수술은 이전 증례와 마찬가지로 내시경적 비내접근법으로 양안의 안구 내벽 및 하내벽감압 술을, 외부접근법으로 안와 외벽감압술을 시행하였다. 수술 직후 복시 등 수술과 관련된 합병증은 발생하지 않았으며, 술 후 1 개월째 우안의 시력 0.5 로 호전되었고 안구돌출계는 우 안 $19 \mathrm{~mm}$, 좌안 $18 \mathrm{~mm}$ 로 우안 $6 \mathrm{~mm}$, 좌안 $5 \mathrm{~mm}$ 의 안구돌 출 교정효과가 있었고 복시 및 안구운동 제한도 호전되었다. 현재 수술 후 3 개월째 안구돌출 등의 재발 없이 경과관찰 중 이다(Figs. 5B, 6C and D).

\section{고 찰}

2008년 European Group on Graves' Orbitopathy(EUGO$\mathrm{GO})$ 의 갑상샘 눈병증의 치료에 대한 표준지침에 따르면, 경
증 갑상샘 눈병증은 금연, 갑상샘 기능 유지, 인공눈물 등의 보조적인 대증요법만 권하며 중등도-중증 갑상샘 눈병증은 면역 억제요법이나 수술요법이 필요하다. ${ }^{8)}$ 특히 스테로이드는 항염증 및 면역 억제 작용뿐 아니라 증상을 호전시켜 우선적 으로 사용하도록 권하고 있으며 방사선 조사요법도 시도되고 있으나 이러한 치료에 반응하지 않거나 복시, 시력 감퇴 등이 발생하면 수술을 고려해야 한다. ${ }^{8)}$

갑상샘 눈병증 환자의 수술적 치료로 1911년 Dollinger에 의 하여 외벽감압술이 처음으로 시행되었다. ${ }^{1,9)} 1950$ 년에 Hirsch 는 안와 하벽의 제거를 시도하였고, Walsh와 Ogura는 안와 하 벽 및 내벽을 제거하여 약 4 6 $\mathrm{mm}$ 의 안구돌출 교정효과를 얻을 수 있다고 보고하였다. ${ }^{1,9)}$ 보통 안와 하벽과 내벽의 감압 술이 많이 사용되고 있으며, 새로운 복시의 발생이 가장 흔한 합병증으로 알려져 있다. 수술 후 복시의 발생은 수술 방법 및 문헌에 따라 약 $30 \%$ 에서 많게는 $60 \%$ 까지 보고되며, 안 구의 내측 또는 하방 편위 때문에 발생하는 것으로 생각된 다. ${ }^{10-12)}$ 이에 Graham 등슨 안와 내벽과 하벽 및 외벽을 균형 있게 감압하는 균형감압술(balanced decompression)을 이용 하면 수술 후 복시의 발생을 $10 \%$ 정도로 줄일 수 있다고 하 였으며, 본 증례에서도 안와 외벽감압술을 같이 시행하였으 며 새로운 복시 등의 합병증은 발생하지 않았다. ${ }^{13)}$ 수술 시 제 거하는 안와벽의 제거 개수에 따라 두벽감압술( 2 wall decom- 
pression)과, 세벽감압술(3 wall decompression)이 있으며, 대개 안구돌출 정도가 심한 경우에 세벽감압술을 시행한다. European Group on Graves' Orbitopathy의 연구에 따르면 같은 정도의 안구돌출에서 교정효과는 두벽감압술에서 4.3 $\mathrm{mm}$, 세벽감압술에서 $6.0 \mathrm{~mm}$ 정도로 더 큰 것으로 보고하였 다. ${ }^{12)}$ 저자의 보고에서 앞의 두 증례에서는 세벽감압술을 하 였지만 모두 $4 \mathrm{~mm}$ 정도 안구돌출이 호전되었는데, 이는 안 와 하벽 및 외벽의 감압 정도가 충분치 않아서라고 생각되 며, 감압 정도를 증가시킨 마지막 증례에서는 $6 \mathrm{~mm}$ 정도의 안구돌출 호전 결과가 있었다. 최근 안와감압술 시행 시 합병 증을 최소화하면서 수술 효과를 최대로 증대시키기 위한 노 력이 진행되고 있다. 국내에서 Lee 등 ${ }^{14)}$ 은 수술 전 컴퓨터단 층촬영 사진으로 외안근 및 안와 지방의 침범 정도를 평가하 고 수술 중 안구돌출 정도를 평가하여 그에 따라 수술 방법 을 달리하는 단계적 감압술(graded decompression)을 소개 하였다. 또 다른 보고에서는 기존 신경외과 영역에서 사용되 던 정위적 수술 항해 장치를 이용하면 좀 더 안전하고 효과 적인 안와감압술을 시행할 수 있다고 하였다. ${ }^{15)}$ 시력 호전의 정도를 보면 Levy 등 ${ }^{6}$ 과 Tang 등)에 의한 보고에서 압박 시 신경 병증 환자에서 내시경을 이용한 안와감압술 후 모든 예 에서 확연한 시력의 개선을 보였다고 하였으며, 본 보고의 첫 증례에서도 1.0 으로 만족할 만한 시력 회복을 보였다.

갑상샘 눈병증 환자에서 내시경을 이용한 비내접근법의 장 점으로 흥터가 남지 않는다는 점에서 미용적인 효과가 있으 며, 출혈 및 부종의 감소 등으로 수술 후 기능적인 회복 또한 기존 수술법에 비해 유리할 것으로 보이고, 내시경을 이용하 면 시신경 및 안와 구조물이 밀집해 있는 뒤쪽까지 쉽게 접 근하여 감압할 수 있으므로 첫 증례와 같이 갑상샘 눈병증 환자에서 압박시신경병증을 동반하는 경우 더욱 효과적이라 고 보고된다. ${ }^{67)}$ 내시경수술 시 문제점으로 지적되던 수술 시 야의 협소함 및 기구 사용의 어려움 등은 장비의 발달에 힘입 어 개선되고 있으며, 내시경을 활용하는 수술 분야가 늘어나 면서 술자의 숙련도 및 기구의 편리성도 점차 증대되고 있다. 아직 이비인후과에서는 내시경을 이용한 비강 내 접근법이, 안과에서는 결막 경유법 등의 외부접근법에 익숙하다. 하지 만 안와 내벽 및 하벽뿐만 아니라 복시 등의 합병증을 줄여 주고 수술 결과도 극대화할 수 있는 외벽감압술도 같이 시행 하면 더 좋은 결과를 얻을 수 있을 것이라고 생각되며, 향후 본 증례와 같이 갑상샘 눈병증 환자에서뿐만 아니라 안와골
절, 안와종양 등의 분야에서 내시경을 이용한 비내접근법은 더욱 유용하게 활용될 수 있을 것으로 보인다. 저자들은 세 명 의 갑상샘 눈병증 환자에서 비내시경을 이용한 안와 내벽 및 내하벽 안와감압술과, 외안각 접근법을 이용한 외벽감압술을 시행하였으며, 특별한 합병증 없이 안구돌출 및 시력이 호전 되었기에 문헌고찰과 함께 보고하는 바이다.

\section{REFERENCES}

1) Siracuse-Lee DE, Kazim M. Orbital decompression: current concepts. Curr Opin Ophthalmol 2002;13(5):310-6.

2) Goh MSY, McNab AA. Orbital decompression in Graves' orbitopathy: efficacy and safety. Intern Med J 2005;35(10):586-91.

3) Boboridis KG, Bunce C. Surgical orbital decompression for thyroid eye disease. Cochrane Database Syst Rev 2011;(12):CD007630.

4) Michel O, Oberländer N, Neugebauer P, Neugebauer A, Rüssmann W. Follow-up of transnasal orbital decompression in severe Graves' ophthalmopathy. Ophthalmology 2001;108(2):400-4.

5) Paridaens DA, Verhoeff K, Bouwens D, van Den Bosch WA. Transconjunctival orbital decompression in Graves' ophthalmopathy: lateral wall approach ab interno. Br J Ophthalmol 2000;84(7):775-81.

6) Levy J, Puterman M, Lifshitz T, Marcus M, Segal A, Monos T. Endoscopic orbital decompression for Graves' ophthalmopathy. Isr Med Assoc J 2004;6(11):673-6.

7) Tang IP, Prepageran N, Subrayan V, Tajunisah I. Endoscopic orbital decompression for optic neuropathy in thyroid ophthalmopathy. Med J Malaysia 2008;63(4):337-8.

8) Bartalena L, Baldeschi L, Dickinson A, Eckstein A, Kendall-Taylor $\mathrm{P}$, Marcocci C, et al. Consensus statement of the European Group on Graves' orbitopathy (EUGOGO) on management of GO. Eur J Endocrinol 2008;158(3):273-85.

9) Lund VJ, Larkin G, Fells P, Adams G. Orbital decompression for thyroid eye disease: a comparison of external and endoscopic techniques. J Laryngol Otol 1997;111(11):1051-5.

10) Mainville NP, Jordan DR. Effect of orbital decompression on diplopia in thyroid-related orbitopathy. Ophthal Plast Reconstr Surg 2014;30 (2): $137-40$.

11) Graham SM, Brown CL, Carter KD, Song A, Nerad JA. Medial and lateral orbital wall surgery for balanced decompression in thyroid eye disease. Laryngoscope 2003;113(7):1206-9.

12) European Group on Graves' Orbitopathy (EUGOGO), Mourits MP, Bijl H, Altea MA, Baldeschi L, Boboridis K, et al. Outcome of orbital decompression for disfiguring proptosis in patients with Graves' orbitopathy using various surgical procedures. Br J Ophthalmol 2009; 93(11):1518-23.

13) Unal M, Leri F, Konuk O, Hasanreisoğlu B. Balanced orbital decompression combined with fat removal in Graves ophthalmopathy: do we really need to remove the third wall? Ophthal Plast Reconstr Surg 2003;19(2):112-8.

14) Lee KH, Jang SY, Lee SY, Yoon JS. Graded decompression of orbital fat and wall in patients with Graves' orbitopathy. Korean J Ophthalmol 2014;28(1):1-11.

15) Lim KS, Lee JK. Evaluation of stereotactic navigation during orbital decompression in thyroid-associated orbitopathy patients. J Korean Ophthalmol Soc 2014;55(3):337-42. 